\title{
Preservation of somatostatin secretion in cystic fibrosis patients with diabetes
}

\author{
L R Meacham, D B Caplan, L P McKean, C N Buchanan, J S Parks, F L Culler
}

\begin{abstract}
Immunohistochemical studies of pancreatic tissue from patients with cystic fibrosis associated with diabetes mellitus (CFDM) show increased numbers of somatostatin secreting delta cells. To look for a possible functional correlate to this finding basal and arginine stimulated plasma somatostatin and serum $\mathrm{C}$ peptide concentrations in eight insulin treated patients with cystic fibrosis and eight normal male controls were measured. Mean basal somatostatin concentrations were not different in the two groups. Mean peak somatostatin concentrations were significantly higher in the group with CFDM: $11.60 \mathrm{pmol} / 1$ v $7 \cdot 14 \mathrm{pmol} / 1$ in controls. Mean peak $\mathrm{C}$ peptide concentrations were significantly lower in the group with cystic fibrosis: $0.89 \mathrm{nmol} / 1$ v $4.27 \mathrm{nmol} / 1$ in controls. This observation provides a physiological correlate to the pathological finding of increased somatostatin content in pancreatic tissue from patients with CFDM. Selective preservation of somatostatin secretion in patients with cystic fibrosis may further complicate pancreatic endocrine insufficiencies through paracrine inhibition of insulin and glucagon secretion.
\end{abstract}

(Arch Dis Child 1993;68:123-5)

As patients with cystic fibrosis are living longer, many are experiencing problems with impaired glucose tolerance and diabetes mellitus. ${ }^{12}$ Progressive loss of ability to secrete insulin in response to various stimuli has been well characterised in patients with cystic fibrosis. This insulin deficiency is considered to be a primary factor in the development of hyperglycaemia. ${ }^{3}$ Approximately $50 \%$ of older patients with cystic fibrosis have documented episodes of hyperglycaemia. ${ }^{56}$ When hyperglycaemia in cystic fibrosis associated with diabetes mellitus (CFDM) leads to symptoms of polyuria, nocturia, dehydration, and weight loss medical intervention becomes necessary. This can complicate an already difficult therapeutic regimen for these patients.

CFDM is different from type I insulin dependent diabetes mellitus. The degree of hyperglycaemia in CFDM is variable and is affected by the pulmonary health of the patient, treatment with glucocorticoids, and the use of nocturnal feedings. A major difference between type I diabetes and CFDM is a relative lack of glucagon secretion in CFDM patients. ${ }^{3}{ }^{4}$ Lower concentrations of glucagon, coupled with diminished but not absent insulin secretory capacity, explain the infrequent occurrence of ketoacidosis in patients with CFDM. $^{6}$

A third pancreatic hormone, somatostatin, may have an important paracrine role in the pancreas in cystic fibrosis. Previous histological studies have demonstrated a relative preservation of somatostatin secreting delta cells in pancreatic tissue from patients with CFDM. ${ }^{78}$ This finding is surprising as it suggests that the 'scarring process' damaging the endocrine pancreas in cystic fibrosis is not affecting all cell types equally. Our study was undertaken to evaluate clinically somatostatin secretion in patients who have CFDM.

\section{Patients and methods}

We measured somatostatin secretion in four boys and four girls with CFDM who were on insulin treatment for a mean of $3.5(0.2)$ years (range $0 \cdot 5-7 \cdot 0$ years). The mean insulin dosage of these patients was $0.7(0.2)$ units $/ \mathrm{kg} /$ day. Eight normal males served as control subjects. The table shows the characteristics of the two study groups. The night before testing, all subjects were instructed to eat nothing after midnight and those with CFDM omitted their morning insulin injection on the day of study. No subjects were taking glucocorticoid hormones as part of their cystic fibrosis treatment regimen. All subjects were considered to be in their usual state of health, and none were hyperglycaemic as assessed by baseline glucose concentrations on the day of testing. Informed consent was obtained from all subjects (and from their parents where appropriate) before participation in the study.

Samples from measurement of baseline fasting blood glucose, somatostatin, $\mathrm{C}$ peptide, and glycated haemoglobin $\left(\mathrm{HbA}_{\mathrm{Ic}}\right)$ concentrations were drawn 30 minutes after placement of an intravenous line. $\mathrm{C}$ peptide concentrations were determined as a reflection of endogenous insulin secretion. ${ }^{9}$ Arginine hydrochloride was then infused at a dose of $0.5 \mathrm{~g} / \mathrm{kg}$ (maximum dose $30 \mathrm{~g}$ ) over 30 minutes as a stimulus for $\mathrm{C}$ peptide and somatostatin release. ${ }^{10} 11$ Blood

Characteristics of the two study groups. Values are mean (SEM)

\begin{tabular}{lll}
\hline & $\begin{array}{l}\text { Patients with } \\
\text { CFDM } \\
(n=8)\end{array}$ & $\begin{array}{l}\text { Normal } \\
\text { controls } \\
(n=8)\end{array}$ \\
\hline Sex $(M / F)$ & $4 / 4$ & $8 / 0$ \\
Age (years) & $22 \cdot 1(1 \cdot 9)$ & $25 \cdot 4(1 \cdot 9)$ \\
Body mass index $\left(\mathrm{kg} / \mathrm{m}^{2}\right)$ & $17 \cdot 7(0 \cdot 8)$ & $23 \cdot 4(0 \cdot 8)$ \\
Fasting glucose $(\mathrm{mmol} / \mathrm{l})$ & $4 \cdot 97(0 \cdot 14)$ & $4 \cdot 59(0 \cdot 07)$ \\
HbA $(\%)$ & $6 \cdot 95(0 \cdot 3)$ & Normal range 4-6.1 \\
Insulin dose (units/kg/day) & $0 \cdot 7(0 \cdot 2)$ & None \\
\hline
\end{tabular}

Correspondence to: Dr Lillian R Meacham 2040 Ridgewood Drive, NE, Atlanta, USA.

Accepted 9 September 1992 
samples for measurement of these two peptides were drawn $15,30,45$, and 60 minutes after arginine infusion was begun. $\mathrm{C}$ peptide radioimmunoassays were performed at the Endocrine Sciences Laboratory, Calabasas Hills, California. Samples for somatostatin were collected in aprotinin (Trasylol, Bayer) and immediately placed on ice until separation of plasma and freezing. Plasma somatostatin concentrations were determined by radioimmunoassay in Dr O'Dorisio's laboratory at Ohio State University. ${ }^{12} \mathrm{HbA}_{1 \mathrm{c}}$ assays (normal range $4 \cdot 0-6 \cdot 1 \%$ ) were performed at Smith Kline Laboratory, Atlanta, Georgia. Baseline blood glucose concentrations were determined using the Accucheck II bedside glucose meter.

Hormone concentrations at different times from the two patient groups were statistically compared using the Student's $t$ test as well as two factor repeated measures analysis of variance followed by Bonferroni multiple comparison procedure. ${ }^{13}$ Rise from baseline was assessed using single factor repeated measures analysis of variance followed by Fisher's least significant difference method. Data are reported as mean (SEM).

\section{Results}

The $C$ peptide responses to arginine are shown in fig 1 . In patients with CFDM there was no significant change in $\mathrm{C}$ peptide concentrations in response to arginine stimulation. The mean $\mathrm{C}$ peptide concentrations were significantly higher in the normal control subjects than in the patients with CFDM with values at baseline of $1.13 v 0.56 \mathrm{nmol} / \mathrm{l}$, values at 15 minutes of $3.28 v 0.83 \mathrm{nmol} / \mathrm{l}$, values at 30 minutes of 4.27 $v 0.86 \mathrm{nmol} / \mathrm{l}$, values at 45 minutes of 3.24 $v 0.89 \mathrm{nmol} / \mathrm{l}$, and values at 60 minutes of $2.02 v$ $0.83 \mathrm{nmol} / 1$.

The somatostatin responses to arginine are shown in fig 2 . Normal subjects failed to show a significant change in plasma somatostatin concentrations from a baseline value of $6.59 \mathrm{pmol} / \mathrm{l}$. Patients with CFDM began at a similar mean

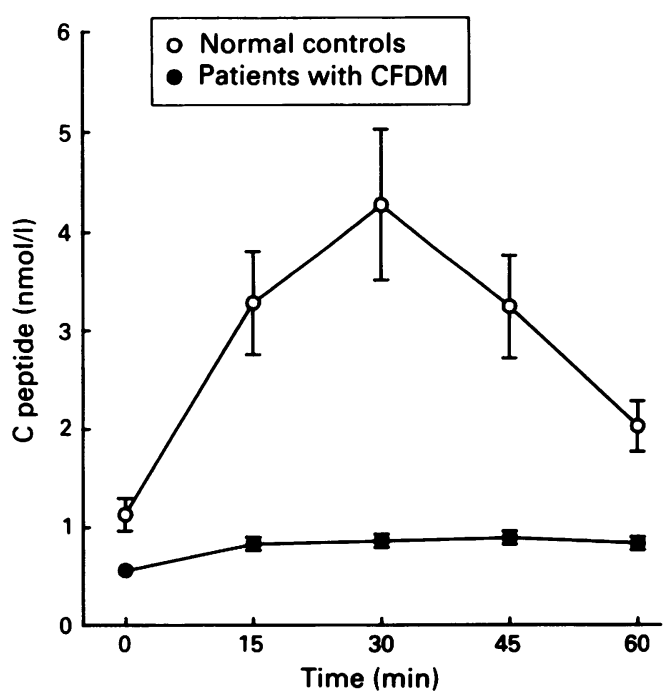

Figure 1 C peptide response to intravenous arginine stimulation $(0 \cdot 5 \mathrm{~g} / \mathrm{kg})$ in normal controls and patients with CFDM. Values are expressed as mean (SEM).

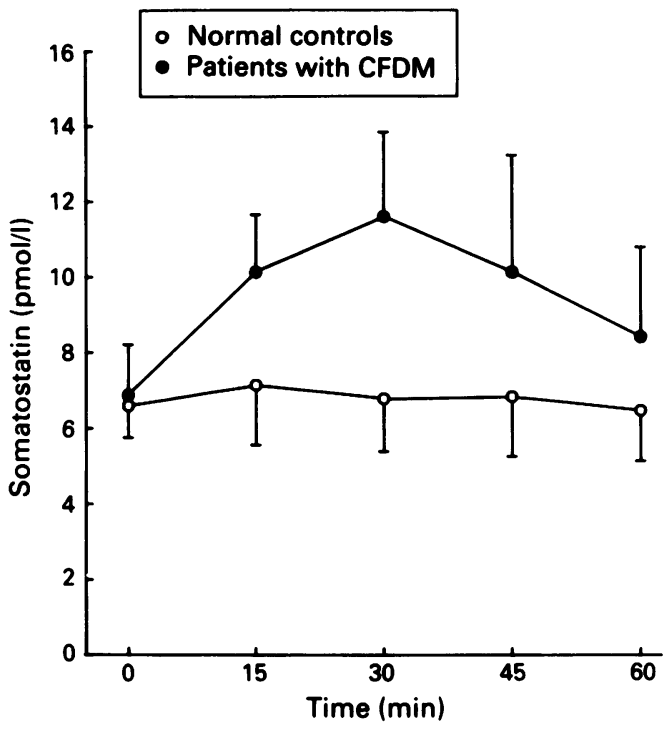

Figure 2 Somatostatin response to intravenous arginine stimulation $(0.5 \mathrm{~g} / \mathrm{kg})$ in normal controls and patients with CFDM. Values are expressed as mean (SEM).

baseline $(6.65 \mathrm{pmol} / \mathrm{l})$, but their mean concentration increased significantly to $11.60 \mathrm{pmol} / \mathrm{l}$ at 30 minutes $(p<0.05)$. Although individual somatostatin responses were highly variable in both subject groups, overall somatostatin responses to arginine stimulation were higher in the group with CFDM. The mean somatostatin concentrations of the two groups were significantly different at 30 minutes with a value in the CFDM group of $11.60 \mathrm{pmol} / 1$ v $6.78 \mathrm{pmol} / 1$ in normal controls, $\mathrm{p}<0.05$.

\section{Discussion}

In patients with cystic fibrosis there is a progressive loss of ability to secrete insulin and glucagon in response to stimuli. ${ }^{4}$ This endocrine failure is clinically recognised as insulin deficiency and CFDM. The pathogenesis of CFDM is different from the destructive autoimmune process resulting in type I diabetes. Islet cell antibodies, a marker of pancreatic autoimmune disease, are rarely found in patients with CFDM. ${ }^{14}$ The endocrine disease process in CFDM is considered pancreatogenic rather than autoimmune and is thought to be due to scarring of the pancreas in cystic fibrosis by inspissation of exocrine secretions.

Pancreatic tissue from patients with cystic fibrosis examined at necropsy shows islets of Langerhans that appear disorganised and strangled by abnormal deposits of collagenous material. ${ }^{5} 8$ Pancreatic specimens have also been evaluated by immunohistochemistry to determine the percentages of various endocrine cell types. ${ }^{7}$ Tissue from subjects with cystic fibrosis on insulin, subjects with cystic fibrosis and normoglycaemia, and normal controls was analysed to determine the percentage of cells which stained positive for insulin, glucagon, and somatostatin. The percentage of cells in the islets which stained positively for insulin were $28.3 \%$ in CFDM, $46.7 \%$ in cystic fibrosis, and $53.4 \%$ in controls. The percentage of cells staining positively for glucagon were $21.9 \%$ in 
CFDM, $25 \cdot 4 \%$ in cystic fibrosis, and $22 \cdot 3 \%$ in controls. The percentage of cells staining positively for somatostatin were $29.3 \%$ in CFDM, $26 \cdot 2 \%$ in cystic fibrosis, and $15 \cdot 5 \%$ in controls. This study demonstrated loss of insulin secreting beta cells, little change in the glucagon secreting alpha cells, but an increase in the percentage of delta cells which secrete somatostatin in patients with CFDM. This apparent preservation of pancreatic delta cells in CFDM led us to question the functional capabilities of the CFDM pancreas for somatostatin secretion.

We have now shown that patients with CFDM are able to secrete somatostatin in response to an arginine stimulus even at a time when insulin secretory capacity is lost. Our data suggest that functional destruction of the pancreatic islets in cystic fibrosis does not involve all cell types equally. This relative preservation of somatostatin secretion may not be unique to cystic fibrosis as Larsen et al have described similarly increased arginine stimulated plasma somatostatin concentrations in six adults with insulin dependent diabetes mellitus secondary to chronic, alcohol induced pancreatitis. ${ }^{15}$

Increased pancreatic somatostatin may contribute to the emergence of hyperglycaemia in the cystic fibrosis population through paracrine inhibition of insulin secretion. In type I diabetes, hyperglycaemia, polyuria, and polydipsia develop after loss of approximately $80 \%$ of pancreatic beta cells. ${ }^{16}$ Immunohistochemical studies of pancreatic specimens from patients with CFDM show loss of only $50 \%$ of normal beta cell surface area. ${ }^{7}$ In CFDM there appears to be a disparity between immunohistochemical presence of relatively adequate numbers of beta cells but functional failure of insulin secretion. This suggests the possibility that local somatostatin excess might be producing paracrine inhibition of insulin secretion. In addition, immunohistochemical studies of CFDM pancreatic specimens show alpha cell islet volumes similar to normal, yet clinical studies demonstrate a loss of glucagon secretion in response to arginine in patients with CFDM. ${ }^{4}$ Perhaps paracrine somatostatin excess also produces a functional deficiency of glucagon in patients with CFDM. The inhibition of glucagon secretion by somatostatin might explain the propensity for low blood glucose reactions during insulin treatment and the sparsity of ketone formation at times of apparent insulin deficiency in patients with CFDM.

A combination of anatomical and functional pancreatic abnormalities results in a unique form of diabetes in people with cystic fibrosis. The degree of hyperglycaemia in patients with cystic fibrosis is also influenced by changes in clinical circumstances which alter sensitivity to insulin. Treatment of hyperglycaemia in CFDM is different from typical treatment used for type I diabetes. A variety of interventions ranging from dietary restrictions of energy containing liquids, to oral sulphonylureas, and to subcutaneous insulin have proved effective. Close monitoring and flexibility in therapeutic interventions are necessary to avoid hyperglycaemia and hypoglycaemia.

This work was supported by grants from the Cystic Fibrosis Foundation and the Georgia Health Foundation, Inc. We are grateful for the assistance of Joyce Oglesby $R N$ in the performance of clinical testing at the Clinical Research Unit of Emory University Hospital and for the statistical advice of Dr Michael Kutner, professor and director of biostatistics, Emory University School of Medicine.

1 Finkelstein SM, Wielinski CL, Elliot GR, et al. Diabetes mellitus associated with cystic fibrosis. $\mathcal{J}$ Pediatr 1988;112: mellitus

2 Rodman HM, Doershuk CF, Roland JM. The interaction of 2 diseases: diabetes mellitus and cystic fibrosis. Medicine 1986;65:389-97.

3 Lippe BM, Sperling MA, Dooley RR. Pancreatic alpha and beta cell functions in cystic fibrosis. $\mathcal{F}$ Pediatr 1977;9: $751-5$.

4 Moran A, Diem P, Klein DJ, Levitt MD, Robertson RP. Pancreatic endocrine function in cystic fibrosis. $¥$ Pediat 1991;118:715-23.

5 Handwerger S, Roth J, Gorden P, Di Sant Agnese P, Carpenter DF, Peter G. Glucose intolerance in cystic fibrosis. N Engl f Med 1969;281:451-61.

6 Rodman HM, Matthews LW. Hyperglycemia in cystic fibrosis: a review of the literature and our own patient fibrosis: a review of the literature and our own patient
experience. In: Warwick WJ, ed. 1,000 years of cystic fibrosis: collected papers. St Paul: University of Minnesota Press, 1981:67-76.

7 Abdul-Karim FW, Dahms BB, Velasco ME, Rodman HM. Islets of Langerhans in adolescents and adults with cystic fibrosis. Arch Pathol Lab Med 1986;110:602-6.

8 Soejima K, Landing BH. Pancreatic islets in older patients with cystic fibrosis with and without diabetes mellitus: morphometric and immunocytologic studies. Pediat Pathol 1986;6:25-46.

9 Eaton RP, Allen RC, Schade DS, Erickson KM, Standefer J. Prehepatic insulin production in man: kinetic analysis using peripheral connecting peptide behavior. $\mathcal{f}$ Clin using peripheral connecting peption

10 Floyd JC, Fajans SS, Conn JW, et al. Secretion of insulin induced by amino acids and glucose induced by diabetes mellitus. Foumal of Clincal Endocrinology 1968;28:266.

11 Kobayashi T, Sawano S, Itoh T, Kosaka K. Plasma immunoreactive somatostatin response to arginine after glycemic control with continuous subcutaneous insulin infusion in type I diabetics. Diabetes Care 1987;10:286-92.

12 O'Dorisio TM, Mekhiian HS, Ellison EC, O'Dorisio MS Gaginella TS, Woltering EA. Role of peptide radioimmunoassay in understanding peptide-peptide interactions and clinical expression of gastroenteropancreatic actions and clinical expression of gastroent

13 Neter J, Wasserman W, Kutner MH. Statistical methods in clinical medicine. In: Neter J, Wasserman W, Kutner MH, clinical medicine. In: Neter J, Wasserman W, Kutner MH, eds. Applied linear statistical
Richard D Irwin, 1990:587-8.

14 Geffner ME, Lippe BM, Maclaren NK, Riley WJ. Role of autoimmunity in insulinopenia and carbohydrate derangements associated with cystic fibrosis. $\mathcal{J}$ Pediatr 1988;112:419-21.

15 Larsen S, Hilsted J, Tronier B, Worning H. Pancreatic hormone secretion in chronic pancreatitis without residual beta-cell function. Acta Endocrinol (Copenh) 1988;118: 357-64.

16 Srikanta S, Ricker AT, McCulloch DK, Soeldner JS, Eisenbarth GS, Palmer JP. Autoimmunity to insulin, beta cell dysfunction and development of insulin-dependent cell dysfunction and development of ins
diabetes mellitus. Diabetes 1986;35:139-42.

17 Unger RH. The milieu interieur and the islets of Langerhans. Diabetologia 1981;20:1-11. 